\title{
Students' and Teachers' Perceptions and Preferences for Oral Corrective Feedback: Do They Match?
}

\author{
Fateme Saeb \\ Faculty of Foreign Languages, University of Isfahan, Isfahan, Iran \\ E-mail: F.saeb1384@gmail.com
}

Received: 06-11-2016

Published: 01-07-2017
Accepted: 08-01-2017

doi:10.7575/aiac.ijalel.v.6n.4p.32
Advance Access Published: April 2017

URL: http://dx.doi.org/10.7575/aiac.ijalel.v.6n.4p.32

\begin{abstract}
Perceptions and perspectives about corrective feedback (CF) have recently attracted some attention in the $\mathrm{CF}$ literature. Few studies, however, have delved into students' and teachers' CF perceptions and preferences and compared them. This study is an attempt to explore Iranian EFL teachers' and students' perceptions and preferences for different amounts and types of oral corrective feedback. Two parallel questionnaires were used to gather quantitative and qualitative data from twenty eight teachers and eighty six of their students. Results revealed significant differences between teachers' and students' perceptions about the amounts and types of CF and also about different types of errors to be corrected. Contrary to their teachers, students in this study were found to be seeking large amounts of explicit corrective feedback provided by the teacher. As for the pedagogical implications, 'meta-correction' is suggested as a solution to the problem of conflicting CF perceptions of students and teachers and to improve and enhance error correction practices within Iranian EFL context.
\end{abstract}

Keywords: Oral corrective feedback, Perceptions, Students' preferences, Learner autonomy

\section{Introduction}

Interest in corrective feedback (CF) and its role in interlanguage development is not a new issue in the field of language learning and teaching. Hot debates and controversies over its value have abounded since the 1960s. The earliest scholarly debates in this area concentrated on the effectiveness of error correction in general (Cathcart \& Olsen, 1976; Dulay \& Burt, 1977; Hendrickson, 1977, 1980; Hillocks, 1982; Kennedy, 1973; Krashen, 1977; Krashen \& Selinger, 1975; Lalande, 1982; Robb et al., 1986; Semke, 1984), whereas more recent research has examined the differential efficacy of various types of oral corrective feedback (Ashwell, 2000; Bitchener \& Knoch, 2008; Bitchener, Young \& Cameron, 2005; Chandler, 2003; Clark \& Ouellette, 2008; Ellis, 2007; Ellis, Sheen, Murakami, \& Takashima, 2008; Ferris, 1997; Hartshorn, 2008; Loewen \& Nabei, 2007; Sheen, 2007; 2010; Sachs \& Polio, 2007; Saeb, 2014; Saeb, Nejadansari \& Khazaei, 2016).

A new trend in corrective feedback research, however, has been the study of students' and teachers' perceptions and beliefs about corrective feedback (Baker, 2007; Brown, 2009; Diab, 2005; Ferris \& Roberts, 2001; Hyland, 2003; Jean \& Simard, 2011; Lasagabaster \& Sierra, 2005; Lee, 2013; Loewen et al., 2009; Plonsky \& Mills, 2006; Schulz, 2001; 1996). What makes research into this area worthwhile for language pedagogy is the necessity of a relative match between the CF perceptions and preferences of students and teachers. Many studies have revealed the negative effects of a lack of such agreement on the process of language learning and teaching (Garrett \& Shortall, 2002; Green, 1993; McCargar, 1993; Morris \& Tarone, 2003; Noels, 2001; Noels, Clément, \& Pelletier, 1999; Peacock, 2001; Reid, 1987; Terrell, 1977; Tse, 2000). According to Plonsky and Mills (2006) the mismatch between the views of the two groups may cause tension, demotivation, frustration, and other learning conditions which are detrimental to the goal of language learning. In like manner, Lyster, Saito and Sato (2012) believe in the importance of the research on CF preferences, "as it informs practitioners of learners' perspectives and, subsequently, may lead to more effective teaching practice when combined with results from the CF effectiveness research" (p. 7).

Most of the previous studies in the CF perceptions and preferences literature, so far, have concentrated on one side of the desk- they have either addressed students' or teachers' perceptions, with few studies (Amrhein \& Nassaji, 2010; Plonsky \& Mills, 2006) investigating both sides and comparing students' and teachers' views and beliefs about different aspects of corrective feedback. Also, some pieces of research (Loewen et al., 2009; Gass \& Lewis, 2007) have suggested that learners' CF preferences may vary depending on the context in which they are learning language. Most of the studies in this area have been conducted within ESL contexts providing us little evidence about how the CF perceptions and preferences would differ in EFL contexts. Attempting to make up for the aforementioned limitations, the present study explores and compares Iranian students' and teachers' preferences and perceptions about the types and amounts of oral corrective feedback. A unique feature of this study is including the qualitative element of also exploring students' and teachers' reasons for their stated preferences. More specifically, this study aims to answer the following research questions: 
1. What amount of oral CF do Iranian students and teachers prefer, and why?

2. What types of oral CF do students and teachers prefer, and why?

3. What types of errors do students and teachers think should be corrected?

4. Are there differences between students' and teachers' preferences and reasons regarding the usefulness of different amounts of oral $\mathrm{CF}$, types of oral $\mathrm{CF}$, and types of errors to be corrected?

\section{Literature Review}

Research into learner and teacher preferences for oral corrective feedback has generally reported that learners are favourably disposed toward receiving feedback for their errors rather than having them go uncorrected. Many studies have repeatedly shown that students often overwhelmingly support corrective feedback and see it as an indispensable part of their language education (Hedgcock \& Lefkowitz, 1994; Hyland, 2003; Schulz, 2001; Truscott, 1999). Schulz (1996), for example, examined and compared student and teacher beliefs regarding the benefits of corrective feedback in eight American language classes. Ninety percent of the students in her study expressed their desire to have their errors corrected. Similar findings were arrived at in Chenoweth et al.'s (1983) investigation of the opinions about correcting oral errors of non-native speakers by native speaker interlocutors. The non-native speakers generally held positive attitudes toward correction of their errors, and spoke of their wish to receive even more correction.

Despite the general agreement about the overall value of corrective feedback, learners' perceptions and preferences have been suggested by some studies to be influenced by factors such as learners' cultural backgrounds, previous and current language learning experiences, and proficiency levels (Lyster, Saito and Sato, 2012). Brown's (2009) study, for example, aimed to identify and compare, teachers' and students' ideals of effective teacher characteristics. Using a Likert-scale questionnaire, he investigated, among other things, the CF perceptions of students and teachers in first- and second-year classes at an American university. His findings revealed the second-year students -who were at a higher level of proficiency- more in favour of receiving indirect correction for their errors while the first-year students were more inclined toward receiving more explicit types of oral corrective feedback.

Reported by the studies comparing students' and teachers' CF perceptions and preferences, there have been considerable discrepancies and mismatches between the views of the two groups (Brown, 2009; Diab, 2005; Farahani \& Salajegheh, 2014; Han \& Jung, 2007; Jean \& Simard, 2011; Jeon \& Kang, 2005; Yoshida, 2008). The most frequently reported observation has been the students' greater desire for receiving corrective feedback than their teachers' willingness to provide them. The students in Lee's (2013) study, for example, were in favour of receiving explicit and immediate corrective feedback during their oral production, while their teachers were strongly opposed to the idea of correcting all of the students' erroneous utterances. Likewise, in Han and Jung's (2007) study, the students opted for explicit and frequent correction, whereas teachers were found to be relatively reluctant toward providing much correction, supporting the idea that students' free speech should not be interrupted.

Still, there has been some studies finding different sorts of mismatch. Teachers in Yoshida's (2008) study, for instance, used recasts as a corrective feedback move in their classes. Their stated reasons for their choice included limitations in class time and their estimation of learners' cognitive style. Their students, however, wished to have a chance to reflect on their own errors and solve the problem themselves before being provided with the correct forms through recasts.

Whatever shape the mismatch takes, there truly seems to be a gap between what students and teachers believe constitutes effective and useful types and amounts of corrective feedback. Such disagreement and conflict of ideas can be problematic for the process of language learning and teaching. As Amrhein and Nassaji (2010) stated, if the type or amount of feedback provided for the students do not match what they prefer and expect, it may not be useful to them. A clear statement of CF perceptions and preferences, therefore, can help both teachers and students better accomplish the task of language learning and teaching. Such an awareness of preferences and beliefs can be a first step for making an accord between teachers' and students' perceptions which is, as several studies (Diab, 2005; Hyland, 1998; Jeon \& Kang, 2005; Leki, 1991; Plonsky \& Mills, 2006; Raimes, 1991; Saito, 1994; Schulz, 1996, 2001) have suggested, necessary for corrective feedback to be effective. Such has been the motivation for exploring and comparing Iranian students' and teachers' perceptions and preferences for oral corrective feedback in the present study.

\section{Method}

\subsection{Participants}

Eighty six EFL students and twenty eight of their teachers participated in this study. The students were all females between the ages of 13 and 18. They were high school students with a lower intermediate level of proficiency. They came from four different provinces of the country. The teacher group consisted of 20 females and eight males aged between 25 and 44 with their EFL teaching experience ranging from three to twenty two years (11 years on average). The majority of the teachers (48\%) were Ph.D. students, thirty one percent were M.A. holders, and twenty percent held a bachelor's degree in TEFL. Fifty nine percent of the teacher participants were teaching at high schools, while the rest were teachers at language institutes or universities. They were all teaching general English courses to lower- to upperintermediate students. The data was gathered from teachers in 14 different provinces.

\subsection{Instruments and procedure}

Teachers' and students' CF preferences and their reasons were explored using two parallel questionnaires. The items in the questionnaires were mostly adapted from the questionnaire used by Amrhein and Nassaji (2010). A few items were 
added and some items were modified to meet the focus of the study (see Appendices A and B). The questionnaire was designed to elicit both quantitative and qualitative data. The quantitative data was gathered through closed-ended items of different types including multiple choice and Likert-scale items, as well as yes-no questions. The open-ended questions were used to collect qualitative data. In order to make comparing the two groups' responses possible, most of the items in both versions were similarly worded.

Both forms of the questionnaire were pilot tested prior to conducting the target study in order to check for the suitability of wording and the clarity of items. The students' version was given to 20 high-school students with a lower intermediate level of proficiency. The questionnaire for teachers was also administered to a group of seven EFL teachers. Based on the students' and teachers' responses and comments, some modifications were made to the items. The format and layout of the questionnaire were also improved in order to make it easier for the respondents to complete the questionnaire. The data from the pilot study were not used in the target study.

The main data was collected from students and teachers over the course of four weeks on February 2016. The teachers' questionnaires were distributed mostly through email. The student data was gathered by some of the participant teachers who handed the questionnaires to their students and asked them to complete it.

\subsection{Analysis}

Quantitative and qualitative data analyses were employed to analyze the data. For the closed-ended items, frequencies were calculated and then compared using Chi-squares. The Likert-scale items allowed calculating means of the two groups' responses and subsequently using t-tests for the purpose of comparing students' and teachers' responses. Openended questions were analyzed by summarizing student' and teachers' explanations, identifying the recurrent themes and then comparing them.

\section{Results}

\subsection{Amounts of oral corrective feedback}

Questionnaire items number one, two and three addressed the issue of amounts of CF. The first item asked whether they believe the teacher should correct all errors, all major errors, only errors that interfere with communication, or ignore the errors and comment only on ideas and content of the oral production. Table 1 shows the frequencies of students' and teachers' responses and their percentages.

Table 1. Students' and teachers' responses to different amounts of feedback

\begin{tabular}{lcccc}
\hline Options & \multicolumn{2}{c}{ Students } & \multicolumn{2}{c}{ Teachers } \\
\hline & $\mathrm{n}$ & $\%$ & $\mathrm{n}$ & $\%$ \\
a. correct all errors & 44 & 50.5 & 2 & 7.4 \\
b. correct all major errors but not the minor ones & 20 & 22.9 & 7 & 25 \\
c. correct most of the major errors, but not necessarily all of them & 11 & 12.6 & 7 & 25 \\
d. correct only a few of the major errors & 2 & 2.2 & 2 & 7.4 \\
e. correct only the errors that interfere with communicating ideas & 29 & 33.3 & 17 & 62.9 \\
f. correct no errors and respond only to the ideas and content & 1 & 1.1 & 0 & 0 \\
\hline
\end{tabular}

As indicated in the table, the most frequently chosen option by the teachers was correct only the errors that interfere with communicating ideas (62.9). Their second most popular choice was correct most of the major errors, but not necessarily all of them (25.9). Students, on the other hand, mostly chose correct all errors (50.5), and their second choice was correct only the errors that interfere with communicating ideas (33.3). A Chi-Square test was run for each of the options to compare the two groups' answers. The results are presented in table 2. The difference between students' and teachers' responses was significant on options $a$ and $e$. Noting the percentages in table 1 and the ChiSquare results in table 2, it can be inferred that while teachers preferred to correct only the errors that are problematic for communication, students were in favour of receiving correction for all of their errors.

Table 2. Chi-Square results for item one

\begin{tabular}{cccc}
\hline Options & df & Value & Asym. Sig (2-sided) \\
\hline $\mathrm{a}$ & 1 & 14.88 & .000 \\
\hline $\mathrm{b}$ & 1 & .000 & 1.00 \\
\hline $\mathrm{c}$ & 1 & 1.603 & .205 \\
\hline $\mathrm{d}$ & 1 & .389 & .533 \\
\hline $\mathrm{e}$ & 1 & 5.525 & .019 \\
\hline $\mathrm{f}$ & 1 & .000 & 1.00 \\
\hline
\end{tabular}


Explaining the reasons for their choices, the majority of the teachers $(53 \%)$ mentioned the primacy of communication as the goal in language learning and teaching. Also, many of them (32\%) believed that too much error correction discourages or confuses the students and negatively affects fluency. A high frequency of teachers (17.8\%) regarded the purpose of the task as an important factor in the amount of error correction: "If the focus is on accuracy, most errors should be corrected. If fluency is the purpose, then it'll suffice to correct only some errors." An examination of the students' comments yielded five major themes which are summarized in table 3 .

Table 3. Students' reasons for preferring different amounts of CF

\begin{tabular}{lc}
\hline Themes & Percentage of mentions \\
\hline 1. Correcting all errors makes students aware of their problems & 21.8 \\
and prevents them from repeating them. & 12.6 \\
2. Errors affecting communication should be corrected because communication & 11.4 \\
and getting the ideas across is important. & 9.1 \\
3. Correcting all errors helps students learn and perfect their English. & 2.2 \\
4. Correcting too much discourages the students. & \\
5. Not all errors should be corrected because the students & \\
should try to find their own problems.
\end{tabular}

To further explore students' and teachers' opinions about the amounts of feedback, the item number two asked the teachers whether they think they provide their students with enough corrective feedback and asked students whether they think they receive enough corrective feedback from their teachers. All except one teacher answered yes to this questions. Also, in the students' population, only two students thought the feedback they received was insufficient. A Chi-Square test confirmed the lack of a significant difference between students' and teachers' opinions in this regard.

As the last item in this part, item number three asked, "If an error is repeated in a student's speaking more than once, do you think it is useful for the teacher to correct it every time it occurs?" The exact half of the teacher participants answered yes and the other half's answer was no. Among the students, a somewhat similar pattern was observed. Fifty eight percent endorsed the idea of correcting repeated errors while thirty five percent disagreed. A Chi-Square test displayed no significant difference between the two groups' responses to this item $(p=.561)$.

Concerning the teachers' reasons for their preference in this regard, two major explanations was identified for each of the answers yes and no. Twenty eight percent of the agreeing teachers stated that if a repeated error is not corrected each time, it will fossilize. Another fourteen percent believed that repeated correction directs students' attention to their error and help them monitor their oral production. Among the opposing party, the most frequently mentioned answer $(28.5 \%)$ was that repeated correction causes students to lose confidence to speak and communicate. The second favourite reason was the belief that correcting repeated errors leaves no room for learner autonomy and that the students should be given a chance to correct their own errors. The students provided similar accounts of their reasons for their responses. The major themes in the students' explanations are summarized in table 4.

Table 4. Students' reasons for their opinion about repeated correction

\begin{tabular}{lc}
\hline Type of responses & Percentage of mentions \\
\hline 1.The students should try to monitor their own errors & 48.5 \\
after the initial correction. & 11.4 \\
No $\quad$ 2. Correcting each time an error occurs discourages \\
the learner. \\
$\begin{array}{l}\text { 1.Correcting each time an error occurs makes the } \\
\text { correct form stick in the student's mind. }\end{array}$ \\
Yes $\quad$ Repeated correction prevents the error from \\
$\begin{array}{l}\text { being fossilized. } \\
\text { it must be corrected again. }\end{array}$
\end{tabular}


Four items on the questionnaire (items number 4, 5, 6 and 8) asked the participants' views about the different types of oral corrective feedback. In item four, students and teachers were asked to mark their opinion about the usefulness of eight different types of oral $\mathrm{CF}$ on a five-point Likert scale. Each CF type was exemplified and the respondents were asked to rate them from one to five $(1=$ not useful at all, $2=$ not useful, $3=$ doesn't matter, $4=$ quite useful, $5=$ very useful). Students' and teachers' mean scores on each CF type and the t-test results comparing them are represented in table 5 .

Table 5. Students' and teachers' responses to different types of feedback

\begin{tabular}{lcccc}
\hline Feedback Type & Means & t-value & p-value \\
& Students & Teachers & & \\
& 3.02 & 3.55 & 1.96 & .052 \\
a. Recast & 3.10 & 2.62 & -2.19 & .030 \\
b. Explicit correction & 4.10 & 3.11 & -3.83 & .000 \\
c. Explicit correction with metalinguistic explanation & 3.70 & 3.40 & -1.14 & .254 \\
d. Metalinguistic clue & 2.98 & 4.33 & 4.85 & .000 \\
e. Elicitation & 3.31 & 3.62 & 1.08 & .282 \\
f. Repetition & 2.31 & 3.33 & 3.42 & .001 \\
g. Clarification request & 2.79 & 3.44 & 1.94 & .054 \\
h. Paralinguistic signal & & & &
\end{tabular}

As obvious in the table, the difference between the students' and teachers' responses reached the level of significance in all CF types except 'metalinguistic clue' and 'repetition'. Both groups had an overall neutral position toward these two types of error correction. The greatest difference between the students' and teachers' responses was seen in 'elicitation'. While students demonstrated a negative opinion about this feedback type, teachers were positively disposed toward it. For 'explicit correction with metalinguistic explanation', students' mean response was positive (4.10), whereas that of teachers' indicated a neutral position (3.11). Also, about 'clarification request' students demonstrated an overall negative opinion $(M=2.31)$, while their teachers' view was again neutral $(M=3.33)$.

Students' and teachers' explanations for their choices are summarized in tables 6 to 13. For the first type of feedback, i.e. recast, students' most frequent response $(20.25 \%)$ was the idea of recast as an insufficient amount of feedback which fails to make the students aware of the nature of their error. Other students $(8.86 \%)$, and some of the teachers $(14.81 \%)$, believed that recast is a too soon provision of the correct form and that the students should be given a chance to do it themselves. Also expressing a negative view toward this feedback type, a number of students (11.39\%) and teachers $(18.51 \%)$ mentioned that recasts are likely to go unnoticed by the learners as a corrective move (Table 6).

Table 6. Explanations for Recast

\begin{tabular}{lcccc}
\hline Explanations & \multicolumn{2}{c}{ Students } & \multicolumn{2}{c}{ Teachers } \\
\hline & $\mathrm{n}$ & $\%$ & $\mathrm{n}$ & $\%$ \\
Recasts are not useful; they may go unnoticed. & 9 & 11.39 & 5 & 18.51 \\
They do not foster learners' autonomy. & 7 & 8.86 & 4 & 14.81 \\
The teacher should fully explain the error and its reason. & 16 & 20.25 & 0 & 0.0 \\
They are useful as in this way the error is corrected not & & & & \\
the person. So the affective factors are taken care of. & 0 & 0.0 & 3 & \\
& & &
\end{tabular}

For explicit correction, the majority of the students (12.65\%) stated that like in the case of recast, they need explanation about the nature of their error and how exactly to correct it. They predicted that it may increase the possibility of repetition of the same error in future. A number of the students $(8.86 \%)$ also believed that the explicit mentioning of the occurrence of an error by the teacher might be face-threatening for the student. Teachers' opinions, on the other hand, varied more. Some teachers $(7.40 \%)$ mentioned that explicit correction hinders communication. Another seven percent also held that it leaves little room for the learner's autonomy (Table 7). 
Table 7. Explanations for explicit correction

\begin{tabular}{lcccc}
\hline Explanations & \multicolumn{2}{c}{ Students } & \multicolumn{2}{c}{ Teachers } \\
\hline & $\mathrm{n}$ & $\%$ & $\mathrm{n}$ & $\%$ \\
It is not useful; the students themselves should & 5 & 6.32 & 2 & 7.40 \\
try to find the correct form. & & & & \\
It decreases student's motivation. & 3 & 3.79 & 0 & 0.0 \\
It is harmful for the learner' self-esteem. & 3 & 3.79 & 2 & 7.40 \\
It makes the learner nervous. & 1 & 1.26 & 0 & 0.0 \\
The students need full explanation in order to & 10 & 12.65 & 0 & 0.0
\end{tabular}

understand their error and not to repeat it.

For explicit feedback with metalinguistic explanation, the majority of the students (35.44\%) and many teachers $(25.92 \%)$ confirmed a fair level of usefulness as it specifies the erroneous part, explains the reason completely and gives the correct form as well. Some students (7.59\%), however, considered it detrimental to learner's autonomy and expressed their wish to do some part of the job themselves. Fourteen percent of the teachers also stated that during a speaking task is not the right time to provide metalinguistic explanation as it disrupts the flow of speech and disturbs the student's concentration (Table 8).

Table 8. Explanations for explicit feedback with metalinguistic explanation

\begin{tabular}{lllll}
\hline Explanations & \multicolumn{2}{c}{ Students } & \multicolumn{2}{c}{ Teachers } \\
\hline & $\mathrm{n}$ & $\%$ & $\mathrm{n}$ & $\%$ \\
It is useful; it provides full explanation as well as & 28 & 35.44 & 7 & 25.92 \\
the correct form. & & & & \\
The students must have a chance to correct themselves. & 6 & 7.59 & 0 & 0.0 \\
As the purpose in speaking tasks is communication, & 0 & 0.0 & 4 & 14.81 \\
providing metalinguistic explanation is not tenable. & & &
\end{tabular}

providing metalinguistic explanation is not tenable.

For metalinguistic clue, the majority of both students (17.72\%) and teachers $(48.14 \%)$ valued learner autonomy and explained that this type of CF makes students think about their own errors and find the right answer. A teacher commented that it "provides some scaffolding and gives the student the opportunity to self-correct herself". Another teacher expressed the interesting idea that "this way the students are trusted somehow". The second most common explanation for this type of feedback from both students $(3.79 \%)$ and teachers $(11.11 \%)$ was its inappropriateness for lower level students as they have not acquired the rule yet and will not be able to provide the correct form independently. Nonetheless, they appreciated the fruitfulness of metalinguistic clue for higher level students (Table 9).

Table 9. Explanations for metalinguistic clue

\begin{tabular}{lllll}
\hline Explanations & \multicolumn{2}{c}{ Students } & \multicolumn{2}{c}{ Teachers } \\
\hline & $\mathrm{n}$ & $\%$ & $\mathrm{n}$ & $\%$ \\
It is useful; it makes the students think. & 14 & 17.72 & 13 & 48.14 \\
It is challenging and results in more meaningful learning. & 0 & 0.0 & 2 & 7.40 \\
It is useful as it provides scaffolding for self-correction. & 0 & 0.0 & 1 & 3.70 \\
It is not useful for lower levels of proficiency but is suitable & 3 & 3.79 & 3 & 11.11 \\
for more proficient learners. & & & & \\
The teacher should provide explicit indication of the & 7 & 8.86 & 0 & 0.0
\end{tabular}

erroneous part as well as the correct form.

Similar to the case of metalinguistic clue, for elicitation, the most common explanation both from teachers (44.44\%) and students (13.92) was the idea of promoting learner autonomy. One of the teachers explained that using this 
feedback type "students are actively involved in the production of the correct form." A number of the students (7.59\%), however, stressed that it is the teacher's responsibility to specify the error and correct it. Some of the students $(6.32 \%)$ and teachers $(7.40 \%)$ also suggested that the students might not understand what the teacher expects them to do and that this CF type might end up as a confusing procedure for treating errors (Table 10).

Table 10. Explanations for elicitation

\begin{tabular}{lcccc}
\hline Explanations & \multicolumn{2}{c}{ Students } & \multicolumn{2}{c}{ Teachers } \\
& $\mathrm{n}$ & $\%$ & $\mathrm{n}$ & $\%$ \\
It is quite useful as the students should think about & 11 & 13.92 & 12 & 44.44 \\
the mistakes they have made, and correct them. & & & & \\
The student may not understand what was wrong with & 6 & 7.59 & 0 & 0.0 \\
her sentence. The teacher should correct overtly. & & & & \\
It may confuse the learner. & 5 & 6.32 & 2 & 7.40 \\
It can have a long-term effect and might lead to better retention. & 0 & 0.0 & 2 & 7.40 \\
& & & & \\
\hline
\end{tabular}

In line with the other implicit CF types presented above, most of the participants both in the student group (20.25\%) and the teacher group (33.33\%) acknowledged the value of repetition in encouraging learner autonomy. Yet, a portion of the students $(7.59 \%)$ disagreed and supported explicit feedback. Also revealing a negative view toward this feedback type, some students $(5 \%)$ and teachers $(11.11 \%)$ deemed repetition as a face-threatening and stressful tool for error correction. A couple of teachers further noted the possibility that failing to catch the rising intonation students do not recognize the corrective intention of the repetitions and take them as mere exclamations or the teacher's confirming what they have just said (Table 11).

Table 11. Explanations for repetition

\begin{tabular}{lllll}
\hline Explanations & \multicolumn{2}{c}{ Students } & \multicolumn{2}{c}{ Teachers } \\
\hline & $\mathrm{n}$ & $\%$ & $\mathrm{n}$ & $\%$ \\
It helps the student to focus and make & 16 & 20.25 & 9 & 33.33 \\
the correction by themselves. & & & & \\
It can be face-threatening and stressful. & 4 & 5 & 3 & 11.11 \\
It may go unnoticed by the students. & 0 & 0.0 & 2 & 7.40 \\
Repeating the error may fossilize it and is not tenable. & 0 & 0.0 & 2 & 7.40 \\
It is good for higher levels of proficiency. & 0 & 0.0 & 1 & 3.70 \\
& & & & \\
\hline
\end{tabular}

For clarification request, the most frequent explanation from the students (17.72) was that it is not fruitful since it may induce a sense of stress and nervousness in the students. This possibility was referred to only by one person in the teachers group though. Eleven percent of the students and twenty nine percent of the teachers emphasized the potential of this feedback type in catering for learner autonomy. Another common theme in both students' $(2.53 \%)$ and teachers' $(33.33 \%)$ responses was a mentioning of the probability that the clarification request be interpreted by the students as a genuine request for clarification of meaning and content or on the grounds that the teacher has actually missed what they said, rather than a corrective move (Table 12).

Table 12. Explanations for clarification request

\begin{tabular}{lcccc}
\hline Explanations & \multicolumn{2}{c}{ Students } & \multicolumn{2}{c}{ Teachers } \\
\hline & $\mathrm{n}$ & $\%$ & $\mathrm{n}$ & $\%$ \\
& 14 & 17.72 & 1 & 3.70 \\
It is not helpful, as it can cause students & & & & \\
to feel nervous. & 2 & 2.53 & 9 & 33.33 \\
The students may fail to catch its corrective intention. & 9 & 11.39 & 8 & 29.62 \\
It is useful; it gets the learner find her own error. & 9 & 11.39 & 2 & 7.40 \\
The students may get confused and fail to detect & & & &
\end{tabular}


As the last feedback type, paralinguistic signal extracted various explanations from students and teachers. The most frequently cited idea among both students $(27.84 \%)$ and teachers $(29.62 \%)$ was the probable failure of the students to interpret what the teacher means by the signal. A teacher suggested that it might be a double problem for the students: "they should both interpret teacher's gesture and correct themselves. Why not in words?" A couple of teachers also mentioned that it is not practical in the context they teach and that their students are not familiar with body language. Similarly, one of the students commented rather disappointingly that "maybe only one student in a whole class understands what the teacher means by her gesture". Another student even called it a "ridiculous thing to do". In spite of the criticisms levelled against this feedback type, some students $(3.79 \%)$ and teachers $(22.22 \%)$ recognized its usefulness with regard to learner autonomy. Furthermore, twenty two percent of the students and some teachers (11.11\%) demonstrated explanations depicting paralinguistic signal as a valuable learning tool which makes the correct form stick in the learners' mind. To achieve this goal however, a teacher added, "it has to be clear, not confusing or ambiguous." (Table 13).

Table 13. Explanations for paralinguistic signal

\begin{tabular}{lcccc}
\hline Explanations & \multicolumn{2}{c}{ Students } & \multicolumn{2}{c}{ Teachers } \\
\hline & $\mathrm{n}$ & $\%$ & $\mathrm{n}$ & $\%$ \\
$\begin{array}{l}\text { The students may not be able to interpret } \\
\text { what the teacher means by the gesture. }\end{array}$ & 22 & 27.84 & 8 & 29.62 \\
$\begin{array}{l}\text { It invites and requires students to self-correct } \\
\text { the erroneous part of their utterance. }\end{array}$ & 3 & 3.79 & 6 & 22.22 \\
$\begin{array}{l}\text { Paralinguistic information is a good technique } \\
\text { to help students to learn linguistic materials. }\end{array}$ & 18 & 22.78 & 3 & 11.11 \\
\hline
\end{tabular}

On item number six, the participants were asked to specify the type of feedback they believe is most likely to lead to learner uptake. Confirming the results from item four, an inspection of the responses to this item revealed explicit feedback with metalinguistic explanation as the students' most favourite feedback type (35.44\%) and elicitation as the teachers' $(29.62 \%)$. A Chi-Square test showed a significant difference between the students' and teachers' answers to this item $(\mathrm{p}=.001)$.

Addressing the question of who does the correction, item number eight asked students to choose the type of correction they think is most useful. This was a multiple choice item and the options were 'teacher correction', 'self-correction' and 'peer correction'. Table 14 shows students' and teachers' responses to this item as well as the Chi-Square results comparing them.

Table 14. Participants' responses to item eight

\begin{tabular}{lccccc}
\hline Options & \multicolumn{2}{c}{ Students } & \multicolumn{2}{c}{ Teachers } & Chi-Square $\mathrm{p}$ values \\
\hline & $\mathrm{n}$ & $\%$ & $\mathrm{n}$ & $\%$ & \\
Self-correction & 23 & 29.48 & 18 & 66.66 & .001 \\
Teacher correction & 47 & 60.25 & 3 & 11.11 & .000 \\
Peer correction & 8 & 10.25 & 2 & 7.40 & .957 \\
\hline
\end{tabular}

As table 14 reveals, the teacher participants believed in the utmost usefulness of correction when it is done by the learners themselves while their students held that it is most useful when provided by the teacher. The difference between the opinions of the two groups in this regard turned out to be statistically significant. Peer correction was the least favourite among the participants in both groups. Providing reasons for their choosing teacher correction, the students explained that the teacher knows best and if students set out to correct each other or themselves, there is the possibility of making mistakes as a result of their insufficient knowledge. Teachers, on the other hand, supported their choice by stressing the importance of self-correction in longer lasting learning and decreasing the likelihood of repeating errors. One of the teachers also commented that self-correction "helps the learners' awareness, autonomy, and responsibility".

\subsection{Types of errors to be corrected}

Item number nine asked the participants to rate the usefulness of correcting five different types of errors including grammatical errors, vocabulary errors, errors relating to content and ideas, pronunciation errors and stress and intonation errors. This was also a Likert-scale item using the same rating scale as in item four ( $1=$ not useful at all, $2=$ not useful, $3=$ doesn't matter, $4=$ quite useful, $5=$ very useful). Table 15 contains the mean scores from the students and teachers along with the t-test result detecting the significant differences between their responses. 
Table 15. Students' and teachers' responses to different types of errors

Error Type Means

$\begin{array}{cccc}\text { Students } & \text { Teachers } & & \\ 4.54 & 3.59 & -4.73 & .000 \\ 3.80 & 4.37 & 3.08 & .003 \\ 3.66 & 3.66 & .020 & .984 \\ 3.94 & 3.51 & -1.81 & .073 \\ 3.31 & 3.11 & -.824 & .413\end{array}$

As evident in the table, the difference between students' and teachers' responses to this item reached the level of significance in the case of two types of errors, i.e., grammatical and vocabulary errors. Whereas teachers considered correcting vocabulary errors useful, students has an overall neutral view. The reverse is true about grammatical errors; students deemed them a more useful type of error correction than teachers did. For the other three error types, namely, content and ideas, pronunciation, and stress and intonation errors, students' and teachers' opinions generally converged on an overall neutral position.

\section{Discussion}

With the aim of enhancing the current knowledge base on the effectiveness of corrective feedback, this study explored language teachers' and students' beliefs and preferences in this regard. I asked Iranian EFL teachers and students about their perceptions and opinions about different types and amounts of oral corrective feedback, taking note of any possible differences between the attitudes of the two groups. Questionnaire results revealed students and teachers as having various perceptions and preferences in this respect. A comparison of the two groups' perceptions showed both similarities and differences. These results are discussed in detail in this section according to the research questions.

Research question number one asked about the amounts of oral CF which Iranian students and teachers prefer, and their reasons. It was found, based on the results, that most students valued receiving correction for all of their errors. It is noteworthy however, that some students also recognized the importance of correcting errors which influence communication. Teachers, on the other hand, disapproved of correcting all errors and supported correcting errors which interfere with communication of ideas. This discrepancy between the choices of students and teachers extends to their reasoning. While teachers believed that the main aim of language learning is communication and hence correcting every single error is pointless, students observed that correcting all errors makes them aware of their problems and prevents them from repeating errors. This greater desire of the students for receiving CF in spite of their teachers' reluctance to provide it, was also found in Lee's (2013) and Han and Jung's (2007) study.

When asked about the sufficiency of the amount of corrective feedback they receive or provide, both students and teachers unanimously confirmed receiving/providing enough corrective feedback. This results seems contradictory in light of the results from the item number one in which students' and teachers' opinions about the amounts of feedback clashed. The inconsistency might be explainable with respect to the limited number of the participants in this study which bears the need for conducting further investigations with larger samples of students and teachers.

A further similarity between the students' and teachers' preferences and perceptions was observed on the case of correcting repeated errors. Each group was roughly divided into two halves for and against the notion of repeated correction. Students' and teachers' reasoning for their choices also cohered. The favourable explanations were the idea of repeated correction as a learning tool activating learners' conscious attention, as well as a preventer of the fossilization of errors. The opposing students and teachers expressed their concern for learner autonomy and affective factors. This result is consistent with some previous research in which putting students in charge of correcting some of their own errors has been regarded as effective (Ferris \& Roberts, 2001; Hendrickson, 1980; Makino, 1993).

The second research question asked what types of oral CF students and teachers prefer, and why. This was the second area in which the students' and teachers' preferences conflicted. Results from item number four and five indicated that students were more in favour of explicit types of CF and considered error correction to be largely a responsibility of the teacher. Their most favourite CF type turned out to be explicit correction with metalinguistic explanation. Teachers, however, chose more implicit types of feedback which require thought and monitoring on the part of the learners themselves. Students explained that in order to learn effectively and enduringly, they need to see their errors specified and receive detailed explanation as well as being provided with the correct form by the teacher. Expressing the opposite view, teachers demonstrated that they were anxious to promote learner autonomy through encouraging students to locate their own errors and to find the correct form. Results from items number six and eight, enquiring about the most probable type of feedback to lead to learner uptake and about the doer of correction, lent further support to this dichotomy. It seems that students' tendency toward teacher-generated explicit types of CF and teachers' preference for implicit feedback fostering self-correction is a recurring theme in the CF literature as it has been arrived at by some previous studies (Amrhein \& Nassaji, 2010; Brown, 2009; Han \& Jung, 2007; Lee, 2005, 2013). 
The third research question asked about the students' and teachers' opinions about the usefulness of correcting different types of errors. The overwhelming majority of the students emphasized the importance of correcting grammatical errors while their teachers showed positive beliefs about the usefulness of correcting errors related to vocabulary and word choice. The difference between the students' and teachers' opinions was again significant. This finding is in line with the results of previous studies in which students were found to believe in the primacy of correcting form-focused errors (Amrhein \& Nassaji, 2010; Brown, 2009; Hedgcock \& Leftkowitz, 1994; Leki, 1991; Raimes, 1991; Schulz, 1996). One explanation accounting for the students' strong positive opinion about correcting grammatical errors might be the predominance of the traditional views about the nature of language and language learning and the grammar-based curriculum currently prevalent in Iranian foreign language teaching contexts, especially high-school contexts from which the student participants of this study were extracted.

On the whole, despite some similarities between the views of the two groups, students and teachers in this study largely differed in their opinions about different types and amounts of oral corrective feedback. Small numbers of the students were sophisticated enough to mention learner autonomy in their choices and explanations; however, most students in this study strongly approved of receiving large amounts of explicit corrective feedback provided by the teacher. Teachers, au contraire, acknowledged the importance of learner autonomy and chose error correction procedures improving and facilitating it.

\section{Conclusion and pedagogical implications}

The mismatches of students' and teachers' perspectives on different aspects of oral corrective feedback found in this study are no promising situation for language pedagogy and practice. As Brown (2009) cautioned, they might be indicative of important discrepancies between the students and teachers in how they interpret and understand the nature and process of language learning. Students in this study were found to be seeking large amounts of explicit corrective feedback provided by the teacher. This may suggest that they had a tendency to evade the responsibility of error correction which is rightfully theirs if language instruction is to lead to effective and long-lasting learning. Such a desire to pass the buck, as Amrhein and Nassaji (2010) confirmed, is in contradiction to the principal end in language pedagogy, which ideally is helping learners reach the level of autonomy and independence and supplying them with strategies to monitor and manage their own learning. A further faulty perception of the students was the belief in correcting grammatical errors as the most important type of errors to be treated. This might also be suggestive of a defective definition of language as largely a system of rules the knowledge of which is to be learnt declaratively, rather than a means of communication which is best acquired procedurally through usage and practice.

The solution to this problem seems to lie in correcting students' misconceptions about what constitutes effective error correction through informative discussions and conferences with students. Surely there is neither much class time nor much point in engaging students in detailed academic and theoretical explanations for every CF issue raised in the class. However, the students can most probably benefit from their teacher's plain justification and explanation of the rationale behind certain types and amounts of corrective feedback exercised in the classroom. Through this process of "metacorrection" teachers can make attempts to disillusion students regarding their unrealistic expectations and perceptions of error correction.

Finally, this study is limited in some ways which should be taken into consideration while interpreting the results. First, the number of the student and teacher participants was fairly small. Also, despite the fact that the sample included students and teachers from fourteen different provinces of the country, they were not randomly selected. This means that caution must be exercised while generalizing the results. Furthermore, the quantitative and qualitative data were obtained using a survey and like any questionnaire study, this study may unavoidably suffer from the limitations of this data-gathering instrument. More specifically, the researchers had no control over how the participants interpreted and answered the questionnaire items.

\section{References}

Amrhein H.R. \& Nassaji H. (2010) Written Corrective Feedback: What do students and teachers prefer and why? Canadian Journal of Applied linguistics, 13, 95 - 127.

Ashwell, T. (2000). Patterns of teacher response to student writing in a multiple-draft composition classroom: Is content feedback followed by form feedback the best method? Journal of Second Language Writing, 9, 227-257.

http://dx.doi.org/10.1016/S1060-3743(00)00027-8

Bitchener, J., \& Knoch, U. (2008). The value of a focused approach to written corrective feedback. Language Teaching Research, 12, 409-431. http://dx.doi.org/10.1177/1362168808089924

Bitchener, J., Young, S., \& Cameron, D. (2005).The effect of different types of corrective feedback on ESL student writing. Journal of Second Language Writing, 14, 191-205.

http://dx.doi.org/10.1016/j.jslw.2005.08.001

Brown. A. (2009). Students' and teachers' perceptions of effective foreign language teaching: A comparison of ideals. Modern Language Journal, 93, 46-60.

http://dx.doi.org/10.1111/j.1540-4781.2009.00827.x 
Cathcart, R. L., \& Olsen, J. E. W. B. (1976). Teachers' and students' preferences for error correction of classroom conversation errors. In J. F. Fanselow and R. H. Crymes (Eds.), On TESOL '76: Selections based on teaching done at the 10th annual TESOL convention (pp. 41-53). Washington: TESOL.

Chandler, J. (2003). The efficacy of various kinds of error feedback for improvement in the accuracy and fluency of 12 student writing. Journal of Second Language Writing, 12, 267 296. http://dx.doi.org/10.1016/S1060-3743(03)00038-9

Chenoweth, N. A., R. Day, A. E. Chun \& S. Luppescu (1983). Attitudes and preferences of ESL students to error correction. Studies in Second Language Acquisition, 6, 79-87.

http://dx.doi.org/10.1017/S0272263100000310

Clark, H., \& Ouellette, M. (2008). Students' noticing and incorporation of written feedback: A snapshot of ESOL writing instructors' commentary on adult ESOL students' essays. Master's Thesis, University of Texas.

Diab, R. L. (2005). Teachers' and students' beliefs about responding to ESL writing: A case study. TESL Canada Journal, $23,28-43$.

Dulay, H. C., \& Burt, M. K. (1977). Remarks on the creativity in language acquisition. In M. Burt, H. Dulay and M. Finochchiaro (Eds.), Viewpoints on English as a second language (pp. 95-126). New York: Regents Publishing Company.

Ellis, R. (2007). The differential effects of corrective feedback on two grammatical structures. In A. Mackey (ed.), 339 360 .

Ellis, R., Sheen, Y., Murakami, M., \& Takashima, H. (2008). The effects of focused and unfocused written corrective feedback in an English as a foreign language context. System, 36, 353-371.

http://dx.doi.org/10.1016/j.system.2008.02.001

Farahani, A., \& Salajegheh, S. (2015). Iranian teachers' and students' preferences for correction of classroom oral errors: Opinions and responses. Argentinian Journal of Applied Linguistics, 1, 14-25.

Ferris, D. (1997). The influence of teacher commentary on student revision. TESOL Quarterly, 31, 315-339. http://dx.doi.org/10.2307/3588049

Ferris, D., \& Roberts, B. (2001). Error feedback in L2 writing classes: How explicit does it need to be? Journal of Second language Writing, 10, 161-184. http://dx.doi.org/10.1016/S1060-3743(01)00039-X

Garrett, P., \& Shortall, T. (2002). Learners' evaluations of teacher-fronted and student- centered classroom activities. Language Teaching Research, 6, 25-57. http://dx.doi.org/10.1191/13621688021r096oa

Gass, S. \& K. Lewis (2007). Perceptions of interactional feedback: Differences between heritage language learners and non-heritage language learners. In A. Mackey (ed.), 79-99.

Green, J. M. (1993). Student attitudes toward communicative and non-communicative activities: Do enjoyment and effectiveness go together? Modern Language Journal, 77, 1-10. http://dx.doi.org/10.1111/j.1540-4781.1993.tb01938.x

Han, J., \& Jung. J. K. (2007) Patterns and preferences of corrective feedback and learner repair. Korean Journal of Applied Linguistics, 23, 243-260.

Hartshorn, K. (2008). The effects of manageable corrective feedback on ESL writing accuracy. Master's thesis, Brigham Young University.

Hedgcock, J., \& Lefkowitz, N. (1994). Feedback on feedback: Assessing learning receptivity to teacher response in L2 composing. Journal of Second Language Writing, 3, 141-163. http://dx.doi.org/10.1016/1060-3743(94)90012-4

Hendrickson, J. M. (1977). Error analysis and selective correction in the adult ESL classroom: An experiment. ERIC Document Reproduction Services, ED 135260.

Hendrickson, J. M. (1980). The treatment of error in written work. Modern Language Journal, 64, $216-221$. http://dx.doi.org/10.1111/j.1540-4781.1980.tb05188.x

Hillocks, G. Jr. (1982). The interaction of instruction, teacher comment, and revision in teaching the composition process. Research in the Teaching of English, 16, 261-278.

Hyland, F. (1998). The impact of teacher written feedback on individual writers. Journal of Second Language Writing, 7 , 255-286.

http://dx.doi.org/10.1016/S1060-3743(98)90017-0

Hyland, F. (2003). Focusing on form: Student engagement with teacher feedback. System, 31(2), 217-230.

http://dx.doi.org/10.1016/S0346-251X(03)00021-6

Jean, G. \& D. Simard (2011). Grammar learning in English and French L2: Students' and teachers' beliefs and perceptions. Foreign Language Annals 44.4, 465-492. 
Jeon, M., \& Kang, I. (2005). Investigating student preferences in error correction in Korean-language teaching. American Association of Teachers of Korean, 5 (10),

Retrieved from http://www.aatk.org/html/KLA10/MJeonIKang.pdf

Krashen S. D., \& Selinger, H. W. (1975). The essential contributions of formal instructions in adult second language learning. TESOL Quarterly, 9(2), 173-183. http://dx.doi.org/10.2307/3585484

Krashen, S. D. (1977). Some issues relating to the Monitor Model. In H. D. Brown, C. Yorio, and R. Crymes (Eds.), On TESOL '77: Teaching and learning English as a second language: Trends in research and practice (pp. 144-158). Washington: TESOL.

Lalande, J. F. II (1982). Reducing composition errors: An experiment. The Modern Language Journal, 66, 140-149. http://dx.doi.org/10.1111/j.1540-4781.1982.tb06973.x

Lasagabaster,D.\&J. M. Sierra (2005). Error correction: Students' versus teachers' perceptions. Language Awareness 14, 112-127. http://dx.doi.org/10.1080/09658410508668828

Lee, E. J. (2013) Corrective feedback preferences and learner repair among advanced ESL students. System, 41, 217-230. http://dx.doi.org/10.1016/j.system.2013.01.022

Leki, I. (1991). The preferences of ESL students for error correction in college level writing classes. Foreign Language Annals, 24, 203-218. http://dx.doi.org/10.1111/j.1944-9720.1991.tb00464.x

Loewen, S. \& T. Nabei (2007). Measuring the effects of oral corrective feedback on L2 knowledge. In A. Mackey (ed.), $361-377$.

Loewen, S., S. Li, F. Fei, A. Thompson, K. Nakatsukasa, S. Ahn \& X. Chen (2009). L2 learners' beliefs about grammar instruction and error correction. The Modern Language Journal 93.1, 91-104. http://dx.doi.org/10.1111/j.15404781.2009.00830.x

Lyster, R., Saito, K., \& Sato, M. (2013). Oral corrective feedback in second language classrooms. Language Teaching, 1, 1-40. http://dx.doi.org/10.1017/S0261444812000365

McCargar, D. (1993). Teacher and student role expectations: Cross-cultural differences and implications. The Modern Language Journal, 77,192-207. http://dx.doi.org/10.1111/j.1540-4781.1993.tb01963.x

Montgomery, J., \& Baker, W. (2007). Teacher-written feedback: Student perceptions, teacher self-assessment, and actual teacher performance. Journal of Second Language Writing, 16, 82-99. http://dx.doi.org/10.1016/j.jslw.2007.04.002

Morris, F., \& Tarone, E. (2003). Impact of classroom dynamics on the effectiveness of recasts in second language acquisition. Language Learning, 53, 325-368. http://dx.doi.org/10.1111/1467-9922.00219

Noels, K. A., Clément, R., \& Pelletier, L. G. (1999). Perceptions of teachers' communica $\neg$ tive style and students' intrinsic and extrinsic motivation. The Modern Language Journal, 83, 23-33.

http://dx.doi.org/10.1111/0026-7902.00003

Noels, K.A. (2001). Learning Spanish as a second language: Learners' orientations and perceptions of their teachers' communication styles. Language Learning, 51, 107-144. http://dx.doi.org/10.1111/0023-8333.00149

Peacock, M. (2001). Match or mismatch? Learning styles and teaching styles in EFL. International Journal of Applied Linguistics, 11, 1-20.

http://dx.doi.org/10.1111/1473-4192.00001

Plonsky, L., \& Mills, S.V. (2006). An exploratory study of differing perceptions of error correction between a teacher and students: Bridging the gap. Northern Arizona University Applied Language Learning, 16, 55-77.

Raimes, A. (1991). Errors: Windows into the mind. College ESL, 1(2), 55-64.

Reid, J. M. (1987). The learning style preferences of ESL students. TESOL Quarterly, 21, 87-111 http://dx.doi.org/10.2307/3586356

Robb, T., Ross, S., \& Shortseed, I. (1986). Salience of feedback on error and its effect on EFL writing quality. TESOL Quarterly, 20, 83-95. http://dx.doi.org/10.2307/3586390

Sachs, R., \& Polio, C. (2007). Learners' uses of two types of writen feedback on an 12 writing revision task. Studies in Second Language Acquisition, 29, 67-100. http://dx.doi.org/10.1017/S0272263107070039

Saeb, F. (2014). The Effects of Focused and Unfocused Written Corrective Feedback on the Grammatical Accuracy of Beginner EFL Learners. International Journal of Applied Linguistics \& English Literature 3, 22-26.

http://dx.doi.org/10.7575/aiac.ijalel.v.3n.2p.22

Saeb, F., Nejadansari, D., \& Khazaei, A. (2016). A Comparative Study of the Effects of Recasts and Scaffolded Feedback on the Grammatical Accuracy of Elementary EFL Learners. Theory and Practice in Language Studies, 6, 1420-1428. 
http://dx.doi.org/10.17507/tpls.0607.13

Saito, H. (1994). Teachers' practices and students' preferences for feedback on second language writing: A case study of adult ESL learners. TESL Canada Journal, 11(2), 46-70.

Schulz, R. A. (1996). Focus on form in the foreign language classroom: Students' and teachers' views on error correction and the role of grammar. Foreign Language Annals, 29, 343-364.

http://dx.doi.org/10.1111/j.1944-9720.1996.tb01247.x

Schulz, R. A. (2001). Cultural differences in student and teacher perceptions concerning the role of grammar instruction and corrective feedback: USA-Columbia. Modern Language Journal, 85, 244-258. http://dx.doi.org/10.1111/00267902.00107

Semke, H. D. (1984). Effects of the red pen. Foreign Language Annals, 17(3), 195-202. http://dx.doi.org/10.1111/j.1944-9720.1984.tb01727.x

Sheen, Y. (2007). The effect of focused written feedback and language aptitude on ESL learners' acquisition of articles. TESOL Quarterly, 41, 255-284. http://dx.doi.org/10.1002/j.1545-7249.2007.tb00059.x

Sheen, Y. (2010). Differential effects of oral and written corrective feedback in the ESL classroom. Studies in Second Language Acquisition 32, 203-234. http://dx.doi.org/10.1017/S0272263109990507

Terrell, T. D. (1977). A natural approach to second language acquisition and learning. The Modern Language Journal, $61,325-337$.

http://dx.doi.org/10.1111/j.1540-4781.1977.tb05147.x \& http://dx.doi.org/10.2307/324551

Truscott, J. (1999). What's wrong with oral grammar correction? Canadian Modern Language Review, 55, 437-456. http://dx.doi.org/10.3138/cmlr.55.4.437

Tse, L. (2000). Student perceptions of foreign language study: A qualitative analysis of foreign language autobiographies. The Modern Language Journal, 84, 69-84. http://dx.doi.org/10.1111/0026-7902.00053

Yoshida, R. (2008). Teachers' choice and learners' preference of corrective-feedback types. Language Awareness 17.1, 78-93. http://dx.doi.org/10.2167/la429.0 